\title{
Keefektifan Penerapan Problem Based Learning Ditinjau Dari Motivasi, Minat Dan Hasil Belajar Siswa Smp/Mts Se-Kabupaten Sorong
}

\author{
Heny Sri Astutik \\ STKIP Muhammadiyah Sorong \\ henynie@gmail.com
}

\author{
Mukhlas Triono \\ STKIP Muhammadiyah Sorong \\ mukhlas.zines.dad@gmail.com
}

\begin{abstract}
This study aims to describe the effectiveness of the problem-based learning approach and problembased learning approach compared with direct instruction approach in plane solid figure in terms of learning motivation, learning interest, and learning result of junior high school students. This study was a quasi experimental study employing the pretest-posttest nonequivalent control group design. The research population comprised in junior high school students in sorong regency were randomly selected as the research sample with stratified random sampling technique, MTs Al-Ma'arif 1 Aimas and SMP IT Nurul Yaqin Kabupaten Sorong. To test the effectiveness of the problem-based learning approach, the one sample t-test were used. Then, to test the more effectiveness of the problem based learning approach than the direct instruction approach, the MANOVA was carried out and then continued by the t-Benferroni test, and to describe increase the data were analyzed using the normalized gain score. The result of the study show that the problem-based learning approach effective and the problem-based learning approach is more effective than the direct instruction approach, and the means normalized score gain the problem-based learning approach is more than direct instruction approach in term of achievement of learning motivation, lerning interest, and learning result of junior high school in Sorong regency.
\end{abstract}

Keywords: effectiveness, problem based learning, learning result, motivation learning, learning interest, plane solid figure

\begin{abstract}
Abstrak: Penelitian ini bertujuan untuk mendeskripsikan keefektifan problem based learning dan keefektifan problem based learning dibandingkan dengan direct instruction pada pembelajaran bangun ruang sisi datar ditinjau dari motivasi, minat, dan hasil belajar di SMP.Jenis penelitian ini adalah quasi experiment dengan pretest-posttest nonequivalent group design. Populasi dalam penelitian ini adalah siswa SMP se-Kabupaten Sorong dan diambil secara acak dengan teknik stratified random sampling yaituMTs Al-Ma'arif 1 Aimas dan SMP IT Nurul Yaqin Kabupaten Sorong. Untuk menguji keefektifan pembelajaran, dianalisis menggunakan uji one sample t-test. Untuk menguji bahwa problem based learning lebih efektif dari pada direct instruction, dianalisis menggunakan MANOVA yang dilanjutkan dengan uji t-Benferroni dan untuk mendeskripsikan peningkatan dianalisis menggunakan uji score gain ternormalisasi. Hasil penelitian menunjukkan bahwa problem based learning efektif dan problem based learning lebih efektif daripada direct instruction, serta rata-rata skor gain ternormalisasi problem based learninglebih tinggi daripada direct instruction ditinjau dari motivasi, minat, dan hasil belajar siswa SMP se-Kabupaten Sorong.
\end{abstract}

Kata Kunci: keefektifan, problem based learning, hasil belajar, motivasi belajar, minat belajar, bangun ruang sisi datar

\section{Pendahuluan}

Dalam upaya untuk meningkatkan mutu pendidikan khususnya mata pelajaran matematika, para pendidik atau guru dituntut untuk selalu meningkatkan diribaik dalam pengetahuan matematika maupun pengelolaan proses pembelajaran. Dalam Undang-Undang nomor 20 tahun 2003 tentang sistem pendidikan nasional, disebutkan bahwa kewajiban guru diatur dalam pasal 40 ayat (2). Pasal itu menyebutkan bahwa pendidik dan tenaga kependidikan berkewajiban menciptakan suasana pendidikan yang bermakna, menyenangkan, kreatif, dinamis, dan dialogis, serta mempunyai komitmen secara profesional untuk meningkatkan mutu pendidikan. Berpijak dari undang-undang tersebut bahwa peranan guru dalam proses pembelajaran memiliki arti yang sangat penting, sehingga guru diharapkan 
dapat melaksanakan pembelajaran yang bermakna, menyenangkan, kreatif, dinamis, dan dialogis, serta selalu meningkatkan profesional, dalam rangka meningkatkan mutu pendidikan.

Berdasarkan hasil wawancara dengan guru pada saat pra survey diperoleh informasi bahwa model pembelajaran yang digunakan dalam setiap proses pembelajaran kurang bervariatif. Pembelajaran yang berlangsung kurang melibatkan siswa untuk aktif dalam pembelajaran, sehingga menyebabkan pembelajaran matematika terasa membosankan dan susah untuk dipahami, sehingga pembelajaran matematika kurang diminati oleh siswa. Hal ini dapat dilihat dari nilai mata pelajaran matematika SMP se-Kabupaten Sorong pada ujian nasional dimana rata-rata nilai matematika pada ujian nasional memiliki klasifikasi $\mathrm{C}$ yang artinya kemampuan sekolah masih tergolong kurang.

Hasil belajar berkaitan erat dengan penguasaan kompetensi. Penguasaan kompetensi juga penting untuk mencapai tujuan pembelajaran. Baik guru maupun siswa perlu memahami kompetensi yang harus dicapai dalam proses pembelajaran. Dalam peraturan pemerintah dirumuskan secara jelas standar kompetensi dan kompetensi dasar yang harus dikuasai siswa. Dalam hal ini, peran guru menjadi penting untuk dapat mewujudkan pembelajaran secara aktif karena dari beberapa penelitian menunjukkan bahwa penguasaan kompetensi siswa di Indonesia masih rendah sehingga berdampak pada rendahnya hasil belajar siswa.

Berdasarkan data ujian nasional dari Litbang tentang daya serap ujian nasional tahun lalu pada mata pelajaran matematika berdasarkan SKL (Standar Kompetensi Lulusan) terlihat bahwa untuk standar kompetensi memahami bangun datar, bangun ruang, sudut, serta menggunakannya dalam pemecahan masalah memiliki daya serap yang tergolong masih kurang dari pada daya serap SKL yang lain yang diujikan. Hal ini kemudian menjadi salah satu masalah karena hasil belajar kaitanya dengan penguasan standar kompetensi penting dalam mencapai tujuan pembelajaran. Menurut Bell (1981: 102) banyak siswa mengalami kesulitan dalam memvisualisasikan obyek tiga dimensi dan hubungan antara obyek-obyek dalam geometri tersebut, mereka perlu mengkronstruksi dan memanipulasi obyek geometri. Lebih lanjut Bell menyatakan bahwa geometri di SMP perlu disajikan secara informal dan intuitif, Selain itu konsep dan prinsip bangun ruang sisi datar banyak dipakai dalam kehidupan seharihari.

Faktor internal dalam diri siswa yang juga sangat berpengaruh terhadap pencapaian tujuan pendidikan serta hasil belajardiantaranya adalah motivasi belajar siswa, akan tetapi dari hasil pra survey dengan angket motivasi belajar siswa yang diuji cobakan pada 2 sekolah menunjukan hasil yaitu untuk pra survey motivasi, persentase banyak siswa pada tiap-tiap kategori adalah $20 \%$ siswa mempunyai motivasi tinggi, 36\% siswa mempunyai motivasi sedang, dan $40 \%$ siswa mempunyai motivasi rendah, dan 4\% siswa mempunyai motivasi sangat rendah. Hal ini menunjukkan bahwamotivasi belajar matematika sebagian besar siswa masih kurang terhadap pembelajaran matematika.

Kata motivasi berasal dari kata kerja latin "movere" atau "to move" yang berarti bergerak (Arends \& Kilcher, 2010: 57). Dalam bahasa Inggris kata tersebut kemudian diserap dan berubah menjadi kata "motivation" dan diserap lagi dalam bahasa Indonesia sebagai kata motivasi. Namun dalam perkembangannya motivasi diartikan berbeda dari arti kata "movere". Seperti yang dikemukakan oleh Hook \& Vass (2001:65); Uno (2008: 3); Slavin (2006: 317); Winkel (1999: 150); Ormrod (2003: 368-369) ; Woolfolk (2007: 372), motivasi belajar adalah suatu dorongan internal dan subjektif yang menggugah, mengarahkan, dan mempertahankan perilaku siswa secara logis untuk aktif mengikuti kegiatan pembelajaran dengan baik sebagai implementasi keinginan,, dan harapan untuk mencapai tujuan pembelajaran. Dari pengertian di atas jelas bahwa motivasi merupakan alasan yang menyebabkan seseorang melakukan sesuatu dan setiap tindakan motivasi memiliki tujuan, dan tujuan motivasi adalah untuk menggerakkan atau menggugah seseorang agar timbul keinginan dan kemauannya untuk melakukan sesuatu sehingga dapat memperoleh hasil atau mencapai tujuan tertentu. Lebih lanjut Elliot (2000: 332) menyatakan bahwa belajar dan motivasi merupakan faktor 
yang sama-sama penting untuk pencapaian suatu kinerja. Adanya pembelajaran memungkinkan untuk belajar tentang pengetahuan baru dan mendapatkan ketrampilan, sedangkan motivasi sebagai daya pendorong untuk mempertunjukan sesuai yang dipelajari. Hal tersebut berarti belajar dan motivasi menjadi dua faktor yang penting dalam mewujudkan keberhasilan proses pembelajaran. Cohen\& Swerdlik (2005: 550) menjelaskan,

Motivation may be conceptualized as stemming from incentives that are either primarily internal or primarily external in origin. Another way of stating this is to speak of intrinsic motivation and extrinsic motivation. In intrinsic motivation, the primary force driving the individuals involvement in work or satisfaction with work product. In extrinsic motivation, the primary force driving the individual stems from rewards, such as salary and bonuses or from constraints, such as job loss.

Schunk, Pintrinch, \& Meece (2010: 147) menyatakan bahwa "motivated learning is motivated to acquire skills and strategies rather than to perform task". Motivasi belajar adalah motivasi untuk memiliki ketrampilan dan strategi bukannya untuk melakukan tugas-tugas. Dalam belajar sangat diperlukan adanya motivasi. Hasil belajar akan lebih optimal jika disertai dengan motivasi yang tinggi, makin tepat motivasi yang diberikan makin berhasil pada pelajaran tersebut. Hal ini juga diperkuat oleh Middleton and Spanias (2013: 82), dari hasil penelitiannya menunjukkan bahwa keberhasilan dalam matematika sangat dipengaruhi oleh motivasi untuk pencapaiannya. Penjelasan yang lebih rinci tentang motivasi dalam belajar dikemukakan Biggs \& Tang (2007: 47), menurutnya motivasi memiliki dua makna, yaitu yang pertama motivasi menunjuk pada saat dimulainya pelajaran dan yang kedua motivasi menunjuk kepada memelihara ikatan (semangat) selama belajar.

Motivasi belajar dalam penelitian ini terdiri dari motivasi intrinsik dan motivasi ektrinsik, motivasi intrinsik terdiri dari adanya hasrat untuk berhasil (Hook \& Vass, 2001: 65), adanya dorongan dan kebutuhan dalam belajar (Winkel, 1999: 150; Schunk, Pintrich, \& Meece, 2010: 236), dan adanya harapan dan cita-cita masa depan (Santrock, 2011: 441). Sedangkan motivasi ektrinsik dalam penelitian ini terdiri dari adanya penghargaan dalam belajar (Schunk, Pintrich, \& Meece, 2010: 236), adanya kegiatan yang menarik dalam belajar (Williams \& Williams, 2010: 2), adanya lingkungan belajar yang kondusif (Williams \& Williams, 2010: 2), serta Adanya persaingan untuk berhasil (Cohen \& Swedlik, 2005: 550; Deci \& Ryan dalam Woolfolk, 2010: 373).

Faktor internal dalam diri siswa yang lain selain motivasi adalah minat belajar siswa terhadap matematika. Minat mempunyai peranan yang sangat penting dalam perkembangan belajar siswa. Siswa yang menaruh minat pada suatu bidang tertentu, maka akan berusaha lebih keras dalam menekuni bidang tersebut dibanding siswa yang tidak menaruh minat. Akan tetapi hasil pra survey minat yang diuji cobakan pada 2 sekolah menunjukan hasil persentase banyak siswa pada tiap-tiap kategori adalah $13 \%$ siswa mempunyai minat tinggi, $42 \%$ siswa memiliki minat sedang, $38 \%$ siswa memiliki minat rendah, dan $7 \%$ siswa memiliki minat sangat rendah. Hal ini menunjukkan bahwa minat belajar matematika sebagian besar siswa masih kurang terhadap pembelajaran matematika.

Hal yang penting pada minat adalah intensitasnya, secara umum minat termasuk karakteristik afektif yang memiliki intensitas tinggi (Mardapi, 2008: 106). Minat merupakan suatu element dalam diri individu yang menyebabkan seseorang merasa mendapatkan manfaat terhadap objek tertentu atau merasa yang berhubungan dengan objek atau pengetahuan. Hal yang sama diungkapkan oleh Elliott,et.al (2000: 349) bahwa minat serupa dan berhubungan dengan keingintahuan "interest is similar and related to curiosity. Interest is an enduring characteristic expressed by a relationship between a person and a particular activity or object". Lebih lanjut dikatakan bahwa belajar dengan minat akan mendorong siswa untuk belajar lebih baik dari pada belajar tanpa minat. Minat muncul apabila siswa tertarik pada sesuatu.

Mardapi (2008: 106); Nitko \& Brookhart (2007: 448); Gable (1986: 8-9); Schraw \& Lehman (Schunk, et al, 2010: 210); Sax (1980: 473); serta Aiken (1999: 259) mengungkapkan bahwa suatu 
minat dapat diekspresikan melalui suatu pernyataan yang menunjukkan bahwa siswa lebih menyukai suatu hal dari pada hal lainnya, dapat pula dimanifestasikan melalui partisipasi dalam suatu aktivitas. Siswa yang memiliki minat terhadap subjek tertentu cenderung untuk memberi perhatian yang lebih besar terhadap subjek tersebut.

Seifert \& Sutton (2009: 117) kemudian mengatakan bahwa minat siswa beraneka ragam, tergantung bagaimana minat tersebut ditempatkan, berdasarkan hal tersebut, ia membagi minat siswa menjadi 2, yaitu situational interest dan personal interest. Untuk membangkitkan situational interest di dalam kelas, guru dapat menampilkan gambar yang menarik dalam pembelajaran, atau menyelingi pelajaran dengan memainkan musik pendek atau membuat suatu kejutan dalam ujian atau Ulangan. Pada tingkat yang lebih abstrak, siswa mendiskusikan pembelajaran yang tidak seperti biasanya dapat juga memunculkan situational interest ketika mereka adalah siswa yang pertama kali diperkenalkan dengan kompetensi tersebut.

Minat belajar matematika siswa dalam penelitian ini terdiri dari aktif mengikuti kegiatan pembelajaran (Seifert \& Sutton, 2009: 117-118; Nitko \& Brookhart, 2007: 448), tekun mengerjakan tugas individu dan kelompok (Strong, dalam Savickas \& Spokane, 1999: 22 - 23), memahami dan mempelajari matematika (Elliott et. al., 2000: 349; Mardapi, 2008: 106; Seifert \& Sutton, 2009: 117), keingintahuan terhadap pembelajaran matematika (Elliott et. al., 2000: 349; Schunk,et.al, 2010: 210), bertanya di kelas (Mardapi, 2008: 112).

Pembelajaran yang tepat dan disesuaikan dengan tujuan pembelajaran mengakibatkan peserta didik akan lebih memahami materi yang disampaikan guru. Tetapi masih banyak guru yang menggunakan model direct instruction pada setiap proses pembelajaran. Direct instruction merupakan pembelajaran yang berpusat pada guru dengan interaksi yang terstruktur dan berulang. Hal ini akan memberikan pengaruh terhadap proses informasi yang akan menjadi long term memory (Dell'Olio \& Donk, 2007: 95-96; Borich, 2000: 164 ;Killen, 2009: 118).

Istilah direct instruction yang digunakan merujuk pada pola pembelajaran yang terdiri dari guru yang menjelaskan ketrampilan konsep baru kepada sekelompok besar siswa, setelah itu mereka diuji pemahaman mereka dengan berlatih di bawah arahan guru (yaitu praktek dikontrol) dan mendorong mereka untuk terus berlatih di bawah bimbingan guru (praktek dipandu) (Joyce, weil, \& Calhoun, 2004: 314-315).

Langkah-langkah pada pembelajaran dengan direct instruction dalam penelitian ini yaitu menyampaikan tujuan dan mempersiapkan siswa, guru menyampaikan tujuan pembelajaran dan menyiapkan siswa (Killen, 2009: 124); mendemonsrasikan pengetahuan atau ketrampilan, guru menjelaskan kompetensi pembelajaran (Arends, 2012: 304); membimbing pelatihan, guru memberikan latihan soal dan membimbing siswa dalam mengerjakannya (Joice, weil, \& Calhoun, 2004: 314-315); memeriksa pemahaman siswa dan memberikan umpan balik, guru meminta siswa untuk mempresentasikan hasil pekerjaan mereka (Arends, 2012: 304); memberikan praktek dan transfer yang diperluas, guru memberikan tugas mandiri (Muijis \& Reynold, 2008: 48-49)

Dalam kurikulum yang diterapkan di sekolah, guru dalam pembelajaran harus memfasilitasi siswa dengan berbagai kegiatan sehingga siswa mendapat pengalaman belajar yang bermakna. Kurangnya motivasi, minat, dan hasil belajar siswa dapat difasilitasi dengan cara menerapkan pembelajaran yang tepat. Model pemebelajaran yang diharapkan dapat meningkatkan motivsi, minat, dan hasil belajar siswa adalah problem based learning.

Arends \& Kilcher (2010: 326), Idris (2009: 82) mengungkapkan bahwa problem based learningmerupakan salah satu pembelajaran yang menghadirkan masalah dunia nyata dalam proses pembelajaran, sehingga problem based learning dimungkinkan dapat memberikan pengalaman belajar yang bermakna bagi siswa. Problem based learning dimulai dengan asumsi bahwa pembelajaran merupakan proses yang aktif, kolaboratif, terintegrasi, dan konstruktif yang dipengaruhi oleh faktorfaktor sosial dan kontekstual. Problem based learning ditandai juga oleh pendekatan yang berpusat 
pada siswa (students-centered), dengan guru sebagai fasilitator. Problem based learning membuat siswa sadar akan informasi apa yang telah diketahui pada masalah yang dihadapi, informasi apa yang dibutuhkan untuk memecahkan permasalahan tersebut, dan strategi apa yang akan digunakan untuk memperlancar pemecahan masalah.

Delisle (1997: 7) dan Tan (2009: 19) menyatakan bahwa problem based learningdapat diterapkan untuk kelas yang heterogen dengan kemampuan siswa beragam, selain itu problem based learning juga dapat digunakan untuk mengembangkan kreatifitas siswa. Selain untuk meningkatkan kreatifitas problem based learning juga dapat digunakan untuk meningkatkan motivasi seperti yang diungkapkan oleh Birch dalam Maxwell, Mergendoller, Bellisimo (2005: 316) yang menyatakan "problem based learning is the most effective of developing the general qualities of the mind student, to securing an integration of academic and operational approaches.... and to instilling a high level of motivation".

Sintaks untuk problem based learning ada 5 fase diantaranya yaitu Fase 1 Mengorientasikan siswa pada masalah, Fase 2 Mengorganisasikan siswa untuk belajar, Fase 3 Membimbing penyelidikan individual maupun kelompok, Fase 4 Mengembangkan dan menyajikan hasil karya, Fase 5 Menganalisis dan mengevaluasi proses pemecahan masalah. Menurut Arends (2008: 42), berbagai pengembangan problem based learning memberikan model problem based learning memiliki karakteristik diantaranya adalah 1) Pengajuan pertanyaan atau masalah, 2) Berfokus pada keterkaitan antardisiplin, 3) Penyelidikan Autentik, 4) Menghasilkan produk dan memamerkannya, 5) Kolaborasi.

Hasil penelitian relevan sebelumnya yang sesuai dengan penelitian ini adalah penelitian yang dilakukan oleh Astutik (2014: 171) atau yang dilakukan oleh peneliti sendiri dengan judul keefektifan problem based learning pada bangun ruang sisi datar ditinjau dari penguasaan standar kompetensi, motivasi, dan minat siswa SMP, yang dilakukan di SMPN 4 Ngajuk, Jawa Timur hasilnya adalah problem based learning efektif pada bangun ruang sisi datar ditinjau dari penguasaan standar kompetensi, motivasi, dan minat belajar siswa. Bedanya dengan penelitian yang dilakukan sekarang adalah merupakan pengembangan penelitian sebelumnya untuk melihat apakah problem based learning juga efektif diterapkan di SMP/MTs se-Kabupaten Sorong.Hasil penelitian relevan sebelumnya lain yang sesuai dengan penelitian ini adalah penelitian yang dilakukan oleh Mergendoller \& Maxwell (2000: 374-382) yang menyatakan bahwa pembelajaran berdasarkan masalah lebih efektif dibandingkan dengan pembelajaran konvensional, penelitian selanjutnya adalah penelitian yang dilakukan oleh Muhson (2009: 171-182). Hasilnya adalah pembelajaran berdasarkan masalah mampu meningkatkan motivasi belajar siswa. Kemudian penelitian yang dilakukan oleh Mawan (2012: 1) yang hasilnya motivasi belajar siswa dengan pembelajaran berdasarkan masalah lebih tinggi dari pada motivasi belajar siswa dengan pembelajaran langsung.

Berdasarkan uraian di atas, maka yang menjadi tujuan penelitian ini adalah Untuk mendeskripsikan apakah problem based learning dan direct instruction efektif serta untuk mendeskripsikan manakah yang lebih efektif dalam pembelajaran matematika menggunakan problem based learning atau direct instruction ditinjau dari motivasi, minat, dan hasil belajar siswa SMP seKabupaten Sorong.Dan diharapkan dengan adanya penelitian ini akan mampu memberikan sumbangan dalam pembelajaran matematika, terutama yang berkaitan dengan problem based learning dan direct instruction, serta bagaimana keefektifan kedua model pembelajaran tersebut pada pembelajaran bangun ruang sisi datar ditinjau dari motivasi, minat, dan hasil belajar matematika siswa di SMP.

\section{Metode Penelitian}

Jenis penelitian ini adalah eksperimen semu (quasi experiment) dengan desain pretest-posttest nonequivalent comparison-group design. Penelitian ini dilakukan di SMP se-Kabupaten Sorong. 
Adapun populasinya adalah seluruh siswa SMP se-Kabupaten Sorong Tahun Pelajaran 2016/2017 yang terdiri dari 42 sekolah. Sesuai dengan rancangan penelitian, dari 42 sekolah sampel dalam penelitian ini ditentukan dengan teknik stratified random sampling. Strata yang dimaksudkan dalam penelitian ini adalah kategori pencapaian kompetensi lulusan dalam ujian nasional siswa SMP/MTs se Kabupaten Sorong yang berada pada kategori baik dan cukup. Yaitu MTs Al-Ma'arif degan kategori baik dipilih dua kelas yaitu satu kelas diberi perlakuan pembelajaran problem based learning sebagai kelas eksperimen dan satu kelas sebagai kelas kontrol dengan diberi perlakuan direct instruction dan SMP IT Nurul Yaqin Kab. Sorong dengan kategori cukup dipilih 2 kelas juga yaitu satu kelas diberi perlakuan pembelajaran problem based learning sebagai kelas eksperimen dan satu kelas sebagai kelas kontrol dengan diberi perlakuan direct instruction. Variabel bebas dalam penelitian ini adalah problem based learning dan variabel terikatnya adalah ketercapaianmotivasi, minat, dan hasil belajar matematika siswa. Instrumen yang digunakan untuk mengukur hasil belajar matematika siswa adalah tes hasil belajar yang terdiri dari 25 soal pilihan ganda dan 5 soal uraian. Instrumen yang digunakan untuk mengukur motivasi dan minat belajar matematika siswa adalah angket motivasi dan angket minat belajar matematika siswa yang terdiri atas 25 pernyataan yang berbentuk checklist.

Teknik pengumpulan data dilakukan dengan pertama-tama memberikan tes dan angket sebelum perlakuan terhadap sampel yang telah ditentukan. Setelah itu, dilanjutkan dengan pemberian perlakuan berupa penerapan problem based learning dan direct instruction kemudian diakhiri dengan pemberian tes dan angket setelah perlakuan terhadap kedua sampel tersebut. Pada penelitian ini, teknik analisis hasil penelitian dilakukan dengan cara mendeskripsikan dan menganalisis statistik inferensial terhadap hasil penelitian yang diperoleh. Deskripsi dilakukan dengan mencari rata-rata, standar deviasi, varians, skor minimal, dan skor maksimal hasil penelitian yang diperoleh, baik sebelum perlakuan, maupun setelah perlakuan.

Untuk menguji apakah pembelajaran dengan problem based learning dan direct instructionpada pembelajaran bangun ruang sisi datar efektif ditinjau dari motivasi, minat, dan hasil belajar di SMP digunakan uji one sample t-test dengan hipotesis,

$$
\begin{aligned}
& H_{0}: \mu \leq 75 \\
& H_{a}: \mu>75
\end{aligned}
$$

formula untuk uji one sample t-test adalah,

$$
t=\frac{\bar{x}-\mu_{0}}{\frac{S}{\sqrt{n}}}
$$

dengan: $\bar{x}$ nilai rata-rata yang diperoleh, $\mu_{0}$ nilai yang dihipotesiskan $(75,00$ untuk aspek motivasi, minat, dan hasil belajar matematika), $S$ standar deviasi sampel, dan $n$ banyak anggota sampel. Kriteria pengujiannya adalah $\mathrm{H}_{0}$ ditolak jika $t_{\text {hit }}>t_{(\alpha ; n-1)}$.

Untuk menguji kemampuan awal sebelum perlakuan dilakukan uji MANOVA untuk melihat apakah terdapat perbedaan kemampuan awal antara dua kelompok sampel pada pembelajaran bangun ruang sisi datar ditinjau dari aspek motivasi, minat, dan hasil belajar. Setelah diketahui bahwa tidak terdapat perbedaan kemampuan awal antara kedua kelompok sampel, maka untuk hasil tes dan angket setelah perlakuan pun dilakukan uji untuk melihat apakah terdapat perbedaan keefektifan problem based learning dan direct instruction pada pembelajaran bangun ruang sisi datar ditinjau dari aspek motivasi, minat, dan hasil belajar matematika di SMP dengan menggunakan rumus uji MANOVA. Hipotesis uji MANOVA sebagai berikut,

$$
H_{0}=\left(\begin{array}{c}
\mu_{p 1} \\
\mu_{m o 1} \\
\mu_{m i 1}
\end{array}\right)=\left(\begin{array}{c}
\mu_{p 2} \\
\mu_{m o 2} \\
\mu_{m i 2}
\end{array}\right)
$$


formula untuk uji MANOVA adalah,

$$
H_{a}=\left(\begin{array}{c}
\mu_{p 1} \\
\mu_{m o 1} \\
\mu_{m i 1}
\end{array}\right) \neq\left(\begin{array}{c}
\mu_{p 2} \\
\mu_{m o 2} \\
\mu_{m i 2}
\end{array}\right)
$$

$$
T^{2}=\frac{n_{1} \cdot n_{2}}{n_{1}+n_{2}}\left(\bar{y}_{1}-\bar{y}_{2}\right)^{\prime} S^{-1}\left(\bar{y}_{1}-\bar{y}_{2}\right)
$$

dengan: $T^{2}$ Hotelling's Trace, $n_{1}$ banyak anggota sampel I, $n_{2}$ banyak anggota sampel II, $\bar{y}_{1}-\bar{y}_{2}$ mean vektor, dan $S^{-1}$ invers matriks kovariansi.

Setelah memperoleh nilai $T^{2}$ Hotteling's, selanjutnya nilai tersebut ditransformasikan untuk memperoleh nilai distribusi $F$ dengan formula sebagai berikut:

$$
F=\frac{n_{1}+n_{2}-p-1}{\left(n_{1}+n_{2}-2\right) p} T^{2}
$$

(Stevens, 2009, p.151) dengan $p$ banyaknya variabel terikat dan kriteria pengujiannya adalah $\mathrm{H}_{0}$ ditolak jika $\left.F_{h i t} \geq F_{(} \alpha ; p ; n 1+n 2-p-1\right)$

Setelah diketahui bahwa terdapat perbedaan keefektifan, maka selanjtnya dilakukan uji $t$ Benferroni untuk melihat apakah problem based learning lebih efektif dari pada direct instruction pada pembelajaran bangun ruang sisi datar ditinjau dari ketiga aspek tersebut dengan menggunakan hipotesis,

$$
\begin{aligned}
& H_{0}: \mu_{i 1} \leq \mu_{i 2} \\
& H_{a}: \mu_{i 1}>\mu_{i 2}
\end{aligned}
$$

dengan $\mu_{i 1}$ menyatakan rata-rata dari motivasi, minat, dan hasil belajar siswa dengan mengunakan problem based learning dan $\mu_{i 2}$ menyatakan rata-rata dari motivasi, minat, dan hasil belajar siswa dengan mengunakan direct instruction. Formula uji sebagai berikut:

$$
t=\frac{\bar{y}_{1}-\bar{y}_{2}}{\sqrt{\frac{\left(n_{1}-1\right) S_{1}^{2}+\left(n_{2}-1\right) S_{2}^{2}}{n_{1}+n_{2}-2}\left(\frac{1}{n_{1}}+\frac{1}{n_{2}}\right)}}
$$

(Stevens, 2009, p.147) dengan: $\bar{y}_{1}$ nilai rata-rata sampel I, $\bar{y}_{1}$ nilai rata-rata sampel II, $S_{1}^{2}$ varians sampel I, $S_{2}^{2}$ varians sampel II, $n_{1}$ banyak anggota sampel I, $n_{2}$ banyak anggota sampel II, dan kriteria pengujiannya adalah $\mathrm{H}_{0}$ ditolak jika $t_{h i t} \geq t_{t} \frac{\alpha}{p}$, n1+n2-2).

Selain menggunakan uji independent sample t-test untuk melihat peningkatan juga digunakan uji Gain score ternormalisasi untuk menghindari hasil kesimpulan yang akan menimbulkan bias pada penelitian, hal ini disebabkan karena pada nilai tes awal kedua kelompok penelitian sudah berbeda. Formula uji Gain score ternormalisasi adalah sebagai berikut.

$$
<g>=\frac{\%<G>}{\%<G>_{\max }}=\frac{\left(\%<S_{f}>\right)-\left(\%<S_{i}>\right)}{100-\left(\%<S_{i}>\right)}
$$

(Meltzer, 2012, p.126) dengan: $\langle g\rangle$ skor gain ternormalisasi, $\left\langle\mathrm{S}_{\mathrm{f}}\right\rangle$ Skor tes akhir, dan $\left\langle\mathrm{S}_{\mathrm{i}}\right\rangle$ Skor tes awal.

Untuk mengkaitkan kualitas peningkatan motivasi, minat, dan hasil belajar siswa dapat dilihat berdasarkan skor gain ternormalisasi dengan klasifikasi yang disajikan dalam tabel berikut.

Tabel 1. Klasifikasi Interpretasi Nilai Gain Ternormalisasi

\begin{tabular}{cc}
\hline Nilai Gain Ternormalisasi & Interpretasi \\
\hline $0,7<[<\mathrm{g}>]$ & Tinggi
\end{tabular}




\begin{tabular}{rr}
$0,3<[<\mathrm{g}>]<0,7$ & Sedang \\
{$[<\mathrm{g}>]<0,3$} & Rendah \\
\hline
\end{tabular}

Akan tetapi, sebelum melakukan analisis di atas, terlebih dahulu dilakukan uji asumsi terhadap skor motivasi, minat, dan hasil belajar matematika siswa SMP se-Kabupaten Sorong, yaitu uji normalitas multivariat dan uji homogenitas matriks varians-kovarians, baik untuk hasil penelitian sebelum dan setelah perlakuan. Uji normalitas multivariat dilakukan menggunakan uji jarak Mahalanobis $\left(d_{i}^{2}\right)$ dengan kriteria keputusan bahwa populasi dikatakan berdistribusi normal jika sekitar 50\% mempunyai nilai $d_{i}^{2}<\chi_{(p ; 0,5)}^{2}$ (Johnson \& Wichern, 2007: 184). Uji homogenitas matriks varians-kovarians dilakukan dengan menggunakan uji Box's Mdengan kriteria keputusan bahwa populasi dikatakan homogen jika nilai signifikansi $F$ lebih besar dari 0,05 (Rencher, 1998: 139-140).

\section{Hasil Penelitian dan Pembahasan}

Diskripsi pelaksanaan pembelajaran merupakan gambaran yang diperoleh selama penelitian untuk mendukung pembahasan hasil penelitian. Dari gambaran ini akan terlihat kondisi awal dan akhir dari setiap variabel yang diteliti. Deskripsi hasil belajar baik untuk kelompok eksperimen maupun kelompok kontrol bisa dilihat pada tabel berikut.

Tabel 2. DeskripsiTes Hasil Belajar

\begin{tabular}{ccccc}
\hline \multirow{2}{*}{ Diskripsi } & \multicolumn{2}{c}{ Eksperimen } & \multicolumn{2}{c}{ Kontrol } \\
& Awal & Akhir & Awal & Akhir \\
\hline Rata-Rata & 37,43 & 81,71 & 36,68 & 79,05 \\
StandarDeviasi & 9,58 & 3.66 & 7,80 & 3,82 \\
Varians & 91,79 & 13,40 & 60,80 & 14,56 \\
Nilai Maksimum & 57 & 93 & 55 & 89 \\
Nilai Minimum & 24 & 74 & 20 & 70 \\
\hline
\end{tabular}

Berdasarkan hasil analisis statistik deskriptif, seperti yang ditunjukkan tebel di atas, rata-rata tes awal dan tes akhir pada kelompok eksperimen serta kelompok kontrol keduanya meningkat. Ratarata hasil belajar kedua kelompok sudah memenuhi standar ketuntasan minimal yaitu 75 . Dari hasil pretest dan posttest kelas eksperimen, siswa sudah memenuhi standar ketuntasan minimal dengan jumlah siswa yang tuntas sejumlah 98\%, sedangkan pada kelas kontrol yaitu dengan peningkatan 95\%.

Deskripsi motivasi belajar, baik untuk kelompok eksperimen maupun kelompok kontrol bisa dilihat pada tabel berikut.

Tabel 3. Deskripsi Motivasi Belajar Siswa

\begin{tabular}{ccccc}
\hline \multirow{2}{*}{ Diskripsi } & \multicolumn{2}{c}{ Eksperimen } & \multicolumn{2}{c}{ Kontrol } \\
& Awal & Akhir & Awal & Akhir \\
\hline Rata-rata & 78,76 & 81,86 & 76,17 & 79,03 \\
Standar deviasi & 5,76 & 3,63 & 5,39 & 2,63 \\
Nilai maksimum & 90 & 90 & 86 & 83 \\
Nilai minimum & 65 & 70 & 64 & 72 \\
\hline
\end{tabular}

Dari tabel di atas, diperoleh informasi secara keseluruhan rata-rata skor motivasi siswa mengalami peningkatan baik pada kelompok eksperimen maupun pada kelompok kontrol. Rata-rata skor motivasi pada kelompok eksperimen sebelum perlakuan 78,76 berada pada kategori sangat tinggi 
dan setelah perlakuan rata-ratanya meningkat menjadi 81,86 dengan kategori tetap pada rentang sangat tinggi, dimana rata-rata skor yang diperoleh siswa meningkat sebesar 3,10. Pada kelompok kontrol rata-rata skor motivasi sebelum perlakuan 76,17 berada pada kategori sangat tinggi dan setelah perlakuan rata-ratanya meningkat menjadi 79,03 dengan kategori tetap pada rentang sangat tinggi, dimana rata-ratanya meningkat sebesar 2,86 lebih rendah dibandingkan peningkatan pada kelompok eksperimen.

Deskripsi minat belajar, baik untuk kelompok eksperimen maupun kelompok kontrol bisa dilihat pada tabel berikut.

Tabel 4. Diskripsi Minat Belajar Siswa

\begin{tabular}{ccccc}
\hline \multirow{2}{*}{ Diskripsi } & \multicolumn{2}{c}{ Eksperimen } & \multicolumn{2}{c}{ Kontrol } \\
& Awal & Akhir & Awal & Akhir \\
\hline Rata-rata & 75,19 & 79,05 & 73,70 & 76,33 \\
Standar deviasi & 4,47 & 2,28 & 4,41 & 2,62 \\
Nilai maksimum & 82 & 83 & 86 & 81 \\
Nilai minimum & 65 & 74 & 66 & 73 \\
\hline
\end{tabular}

Dari tabel diatas, terlihat bahwa rata-rata skor sebelum dan setelah perlakuan pada kelompok eksperimen serta kelompok kontrol keduanya meningkat. Pada kelompok eksperimen rata-rata skor yang diperoleh siswa meningkat sebesar 3,86 sedangkan pada kelompok kontrol meningkat sebesar 2,63 lebih kecil dibandingkan peningkatan pada kelompok eksperimen.

Uji asumsi normalitas dan homogenitas penguasaan standar kompetensi, motivasi, dan minat belajar siswa sebelum dan sesudah perlakuan, baik untuk kelompok eksperimen dan kelompok kontrol hasilnya secara berturut-turut dapat dilihat pada tabel berikut.

Tabel 5. Hasil Uji Normalitas

\begin{tabular}{ccc}
\hline Kelompok & $\mathrm{d}_{\mathrm{i}}^{2}$ Sebelum Perlakuan & $\mathrm{d}_{\mathrm{i}}^{2}$ Setelah Perlakuan \\
\hline Eksperimen & $51,72 \%$ & $51,72 \%$ \\
Kontrol & $50,00 \%$ & $50,00 \%$ \\
\hline
\end{tabular}

Tabel diatas memperlihatkan bahwa sekitar $50 \%$ mempunyai $d_{i}{ }^{2}<\chi_{(0,5 ; 3)}^{2}$, maka dapat dikatakan bahwa motivasi, minat, dan hasil belajar siswa baik untuk kelompok eksperimen maupun kelompok kontrol berasal dari populasi yang berdistribusi normal multivariate.

Tabel 6. Hasil Uji Homogenitas

\begin{tabular}{ccc}
\hline & Sebelum Perlakuan & Setelah Perlakuan \\
\hline Box'M & 12,467 & 11,587 \\
$F$ & 2,019 & 0,9889 \\
Signifikansi & 0,59 & 0,081 \\
\hline
\end{tabular}

Hasil uji homogenitas yang ditunjukkan pada tabel di atas diperoleh informasi bahwa nilai signifikansi $\mathrm{F}$ lebih besar dari 0,05; atau dengan kata lain matriks varians kovarians kelompok pembelajaran dengan problem based learning dan direct instruction baik sebelum maupun sesudah perlakuan telah memenuhi asumsi homogenitas.

Hasil uji mengenai keefektifan pembelajaran (problem based learning dan direct instruction) pada pembelajaran bangun ruang sisi datar ditinjau dari aspek motivasi, minat, dan hasil belajar matematika siswa dapat dilihat pada tabel di bawah ini. 
Tabel 7. Hasil Uji One Sample t-test

\begin{tabular}{clrrr}
\hline Aspek & Kelompok & \multicolumn{1}{c}{$t_{\text {hit }}$} & \multicolumn{1}{c}{$t_{\text {tab }}$} & Sig \\
\hline \multirow{2}{*}{ Hasil Belajar } & Eksperimen & 13,95 & 2,002 & 0,00 \\
& Kontrol & 8,22 & 2,001 & 0,00 \\
\multirow{3}{*}{ Motivasi } & Eksperimen & 14,40 & 2,002 & 0,00 \\
& Kontrol & 11,88 & 2,001 & 0,00 \\
& Eksperimen & 13,52 & 2,002 & 0,00 \\
& Kontrol & 3,94 & 2,001 & 0,00 \\
\hline
\end{tabular}

Karena nilai signifikansi aspek motivasi, minat, dan hasil belajar kedua kelompok lebih kecil dari 0,05 dan nilai $\boldsymbol{t}_{\boldsymbol{h i t}}>\boldsymbol{t}_{\boldsymbol{t a b}}$. Ini berarti bahwa problem based learning dan direct instruction efektif ditinjau dari aspek motivasi, minat, dan hasil belajar siswa.

Berdasarkan kriteria keputusan pada uji one sample t-testproblem based learning efektif ditinjau darimotivasi, minat, dan hasil belajar matematika siswa. Hal ini karena dalam proses pembelajaran dengan menggunakan problem based learning siswa diorganisasikan ke dalam masalah dunia nyata dengan maksud untuk menyusun pengetahuannya sendiri, mengembangkan inquiry dan ketrampilan berpikir yang dapat diterapkan dalam pembelajaran matematika (Arends \& Kilcher, 2010: 326). Selain itu problem based learning juga cocok untuk kelas yang heterogen dengan kemampuan siswa yang berbeda dan dapat digunakan untuk menumbuhkan kreatifitas dan motivasi belajar. Hal ini yang menyebabkan problem based learning efektif ditinjau dari motivasi, minat, dan hasil belajar matematika siswa. Problem based learning efektif ditinjau dari motivasi, minat, dan hasil belajar sejalan dengan kajian teori dan hasil penelitian. Menurut; Delisle (1997: 7); Mergendoller, \& Bellisimo (2005: 316); dan Muhson (2009: 1).

Hasil uji mengenai apakah terdapat perbedaan kemampuan awal antara kedua kelompok sampel sebelum diberikan perlakuan dan perbedaan keefektifan problem based learning dan direct instruction pada bangun ruang sisi datar ditinjau dari aspek motivasi, minat, dan hasil belajar siswa dapat dilihat pada tabel berikut.

Tabel 8. Hasil Uji MANOVA

\begin{tabular}{ccc}
\hline & Sebelum Perlakuan & Setelah Perlakuan \\
\hline$F_{\text {hit }}$ & 2,606 & 16,713 \\
\hline$F_{\text {tab }}$ & 2,769 & 2,684 \\
\hline
\end{tabular}

Dari tabel di atas terlihat bahwa sebelum perlakuan nilai $F_{h i t}<F_{t a b}$ dan setelah perlakuan $F_{\text {hit }}>F_{\text {tab }}$. Maksudnya, sebelum diberikan perlakuan problem based learning dan direct instruction, kedua kelompok memiliki kemampuan awal yang setara akan tetapi setelah diberikan perlakuan terdapat perbedaan keefektifan problem based learning dan direct instruction pada pembelajaran bangun ruang sisi datar ditinjau dari motivasi, minat, dan hasil belajar matematika siswa SMP seKabupaten Sorong.

Setelah diketahui bahwa terdapat perbedaan keefektifan pembelajaran pada kedua kelompok, maka dilakukan uji lanjut independent sample t-test dengan kriteria benferroni untuk melihat variabel mana yang berkontribusi terhadap perbedaan keefektifan. Secara ringkas hasil uji independent sample t-test dapat dilihat pada tabel berikut ini.

Tabel 9. Hasil Uji Independent Sample t-test

Aspek $\quad t_{\text {hit }} \quad t_{\text {tab }} \quad$ Sig.




\begin{tabular}{llll}
\hline Hasil belajar & 3,858 & 2,429 & 0,000 \\
Motivasi & 4,860 & 2,429 & 0,000 \\
Minat & 6,000 & 2,429 & 0,000 \\
\hline
\end{tabular}

Berdasarkan uji Independent Sample t-Test yang ditunjukkan pada tabel di atas diperoleh nilai $t_{\text {hitung }}>t_{\text {tabel }}$ dengan nilai signifikansi kurang dari 0,017 sehingga dapat disimpulkan bahwa problem based learning lebih efektif dibanding direct instruction ditinjau dari aspek motivasi, minat, dan belajar siswa pada pembelajaran bangun ruang sisi datar di SMP se-Kabupaten Sorong.

Selain menggunakan uji independent sample t-test untuk melihat peningkatan juga digunakan uji Gain score ternormalisasi. Perbedaan perolehan gain ternormalisasi rata-rata $\langle\mathrm{g}\rangle$ dari kelompok eksperimen dan kelompok kontrol untuk aspek ketercapaian standar kompetensi, motivasi, dan minat belajar disajikan dalam tabel berikut

Tabel 10. Perolehan Gain Score Rata-Rata <g>

\begin{tabular}{ccccc}
\hline \multirow{2}{*}{ Aspek } & \multicolumn{2}{c}{ Eksperimen } & \multicolumn{2}{c}{ Kontrol } \\
& Rata-Rata $\langle\mathrm{g}>$ & Kriteria & Rata-Rata $<\mathrm{g}>$ & Kriteria \\
\hline Hasil belajar & 0,7032 & Tinggi & 0,6620 & Sedang \\
Motivasi & 0,1021 & Rendah & 0,0816 & Rendah \\
Minat & 0,1257 & Rendah & 0,0728 & Rendah \\
$\bar{x}$ & 0,3103 & & 0,2721 & \\
\hline
\end{tabular}

Pada tabel diatas tampak bahwa skor gain ternormalisasi rata-rata kelompok eksperimen lebih tinggi dari pada kelompok kontrol. Disamping itu kedua kelompok memiliki kategori skor gain ternormalisasi yaitu sedang dan rendah. Dengan demikian dapat dikatakan bahwa problem based learning pada kelompok eksperimen dapat meningkatkan penguasaan standar kompetensi, motivasi, dan minat belajar siswa lebih baik dari pada pembelajaran menggunakan direct instruction pada kelompok kontrol.

Hasil penelitian ini pun sejalan dengan kajian teoriArends \& Kilcher (2010: 326). yang mengungkapkan bahwa dengan problem based learning siswa yang sebelumnya merasa asing dengan objek-objek bangun ruang sisi datar dengan hanya menghafal rumus dan menyelesaikan soal-soal tanpa memahami apa yang diselesaikan dan apa kegunaan dalam kehidupan sehari-hari menjadi tahu apa yang dikerjakan dan apa manfaatnya dalam kehidupan sebab problem based learning adalah pendekatan pembelajaran yang mengorganisasikan pembelajaran dalam situasi dunia nyata. Peningkatan motivasi, minat, dan hasil belajar matematika juga dimungkinkan karena siswa menemukan masalah matematika yang berkaitan dengan bangun ruang sisi datar dalam kehidupan sehari-hari dan membawanya dalam pembelajaran. Terlihat bahwa siswa termotivasi meningkatkan pengetahuannya dengan tidak hanya mengandalkan soal-soal yang dikerjakan di kelas, tetapi juga aktif menyelesaikan persoalan matematika yang ditemui dalam kehidupan sehari-hari untuk diselesaikan.

Pembelajaran yang diikuti oleh siswa pada kelompok direct instruction kurang berpengaruh baik terhadap motivasi, minat, dan hasil belajar matematika siswa hal ini dimungkinkan karena dalam pelaksanaan pembelajaran dengan direct instruction lebih didominasi oleh kegiatan ceramah guru dimana guru sebagai penyedia informasi utama. Menurut Joyce, Well, \& Calhoun (2004: 314315)direct instruction mengacu pada pola pembelajaran yang terdiri dari penjelasan guru tentang sebuah konsep atau ketrampilan baru kepada siswa dalam kelompok besar atau kelas, pemberian latihan yang disertai petunjuk guru, dan mendorong siswa untuk melanjutkan latihan untuk menguji pemahaman siswa, dalam mode ini pengembangan kemampuan matematika dilakukan melalui penyelesaian latihan soal. 
Dalam pembelajaran matematika dengan menggunakan direct instruction, kegiatan utama terletak pada belajar matematika melalui ceramah guru. Semua konsep matematika yang harus dipelajari oleh siswa disampaikan secara lisan oleh guru. Sebagai pendalaman pembelajaran siswa hanya diberikan contoh dan latihan soal. Berdasarkan pengamatan peneliti siswa tidak terpacu untuk mempelajari kompetensi yang disampaikan karena tidak ada tindak lanjut terhadap kompetensi yang mereka pelajari. Akibatnya siswa menjadi cepat bosan, jenuh, tidak aktif dan tidak kreatif saat proses pembelajaran berlangsung. Siswa hanya belajar jika diberikan waktu untuk menyelesaikan latihan soal. Ketika soal yang diberikan berbeda dengan soal yang dijadikan contoh oleh guru maka siswa mengalami kesulitan menyelesaikan soal dan membutuhkan bimbingan lebih dari guru.

Hal tersebut menyebabkan pembelajaran yang diikuti siswa dalam kelompok direct instruction kurang berpengaruh baik terhadap motivasi, minat, dan hasil belajar matematika siswa karena pembelajaran yang dilaksanakan tidak memacu siswa untuk belajar karena semua konsep matematika yang harus dipelajari oleh siswa disampaikan secara lisan oleh guru kemudian siswa melakukan kegiatan di kelas sesuai arahan penuh guru. Sedangkan dalam problem based learning siswa diberi kesempatan mempelajari kompetensi dengan megaitkan kompetensi yang dipelajari dengan masalah dunia nyata yang diharapkan nantinya siswa dapat menyusun pengetahuan sendiri, menumbuh kembangkan keterampilan secara mandiri dan dapat meningkatkan kepercayaan diri pada siswa.

Dalam proses problem based learningsiswa dipacu untuk berfikir kristis dalam pemecahan masalah sehingga diharapkan siswa memperoleh pengetahuan dan konsep yang jelas. Selain itu problem based learning mengubah arah interaksi pembelajaran yang memungkinkan siswa terlibat aktif dalam pembelajaran sehingga dengan kondisi belajar yang lebih menyenangkan motivasi dan minat belajar siswa terhadap matematika dapat ditingkatkan yang tentunya berpengaruh pula terhadap hasil belajar mereka. Hal ini sejalan dengan penelitian sebelumnya yang dilakukan oleh Mergendoller \& Maxwell (2000: 374-382) yang menyatakan bahwa problem based learning lebih efektif dibandingkan dengan pembelajaran konvensional, penelitian selanjutnya adalah penelitian yang dilakukan oleh Muhson (2009: 171-182). Hasilnya adalah problem based learning mampu meningkatkan motivasi belajar siswa. Kemudian penelitian yang dilakukan oleh Mawan (2012: 1) yang hasilnya motivasi belajar siswa dengan problem based learning lebih tinggi dari pada motivasi belajar siswa dengan direct instruction.

\section{Simpulan dan Saran}

\subsection{Kesimpulan}

Problem based learning dan direct instruction efektif serta problem based learning lebih efektif dari pada direct instruction ditinjau pada aspek motivasi, minat, dan hasil belajar pada standar kompetensi memahami sifat-sifat dan bagian-bagian bangun ruang sisi datar serta menentukan ukuranukurannya pada siswa kelas VIII SMP se-Kabupaten Sorong.

\subsection{Saran}

Meskipun hasil penelitian ini telah sejalan dengan kajian teori dan penelitian yang relevan tetapi seperti yang sudah dijelaskan sebelumnya bahwa terdapat beberapa keterbatasan yang menjadi kendala dalam pelaksanaan penelitian ini. Berdasarkan atas hal tersebut, ada beberapa hal yang disarankan, antara lain: alokasi waktu untuk setiap kegiatan pembelajaran lebih diperhatikan, sebab dalam langkah pembelajaran masalah terdapat fase pengajuan masalah yang membutuhkan alokasi waktu yang lama sebab menuntut siswa untuk mengumpulkan informasi, mengkonstruksi ide-ide dan mengkaitkan pengetahuan yang sudah dimiliki untuk menyelesaikan masalah yang diajukan, selain itu guru harus lebih menekankan bahwa soal yang diajukan dapat diselesaikan karena berkaitan dengan 
dunia nyata dan mungkin berkaitan dengan pengetahuan lain meski siswa belum tahu konsep penyelesaian masalah tersebut.

\section{Daftar Pustaka}

Aiken, L. R. (1999). Personality assessment methods and practices. Seattle,USA: Hogrefe and Huber Publishers.

Arends, R.I. (2008). Learning to teach (terjemahan Helly Prajitmo Soetjipto dan Mulyanti Soetjipto). New York: Mc Graw Hill Companies, Inc. (Buku asli diterbitkan tahun 2007).

Arends, R.I.(2012).Learning To Teach $\left(9^{\text {th }} E d\right)$. New York, NY:McGraw-Hill.

Arends, R.I., \& Kilcher, A., (2010). Teaching for student learning becoming an accomplished teacher. New York, NY: Roudledge.

Astutik, H. S. (2014). Keefektifan pembelajaran berdasarkan masakah pada bangun ruang sisi datar ditinjau dari penguasaan standar kompetensi, motivasi, dan minat siswa SMP. Tesis magister, tidak diterbitkan, Universitas Negeri Yogyakarta.

Bell, F.H. (1981). Teaching and learning mathemathics (In secondary school). Des Moines: Wm. C. Brown Company.

Biggs, J. \& Tang, C. (2007). Teaching for quality learning at university ( $3^{\text {rd }}$ Ed). New York: McGrawHill.

Borich, G. D. (2000). Effective teaching methods. Upper Saddle River, NJ: Merrill.

Cohen, R. J.\& Swerdlik, M. (2005). Psychological testing and assessment: an introduction to tests and measurement (6th ed.). New York.: McGraw-Hill.

Delisle R.(1997). How to use problem based learning in classroom. Alexandria: Assosiation for supervision and curiculum development.

Depdiknas. (2003). Undang-Undang RI Nomor 20 Tahun 2003 Pasal 40 Ayat 2, tentang Sistem Pendidikan Nasional.

Dell'Olio, J. M., \& Donk, T. (2007). Models of teaching: Connecting student learning with standards. Thousand Oaks, California: Sage Publication.

Elliot, S.N., et.al. (2000). Educational psycology: effective teachin, effective learning ( $3^{\text {rd }}$ ed). Boston: Mc. Graw-Hill Companies,Inc.

Gable, R. K. (1986). Instrument development in the affective domain. Boston: Kluwer.

Hook, P., \& Vass, A. (2001). Creating winning classrooms. London: David Fulton Publishers.

Idris, N. (2009). A do it your self estimation in measurement: use of problem based leaning. Journal of educational research. 2009; 80,15 Journal for research mathematic education in university of malaya pg 72.

Johnson, R.A \& Wichern D.W. (2002). Applied multivariate statistical analysis $\left(5^{\text {th }}\right.$ Ed). Upper Saddle River,NJ: Prentice Hall.

Joyce, B., Calhoun, E., \& Weil, M. (2004). Models of teaching. Boston: Person/Allyn and Barcon.

Killen, R. (2009). Effective teaching strategies: lessons from research and practice. Victoria: Cengage Learning Australia.

Mardapi, D. (2008). Teknik penyusunan instrumen tes dan non tes. Yogyakarta: Mitra Cendekia Press.

Mawan. (2012). Komparasi keefektifan pembelajaran dengan problem based learning dan PMRI pada hasil belajar motivasi dan sikap siswa. Tesis magister, tidak diterbitkan, Universitas Negeri Yogyakarta.

Meltzer, D. E. (2002). The relation between mathematic preparation and conceptual learning gain physics: a possible hidden variable in diagnostic pretest score, Artikel 001. Diambil pada tanggal $25 \quad$ September 2014, dari http://physics.iastate.edu/per/dosc/addendum_on_normalized_gain.pdf

Mergendoller, J.R, Maxwell, N.L \& Bellisimo, Y. (2005). Problem based learning and high school; a comparative study of instructional method. Journal of educational research. Fall. 2005; 36,4 Proques Educational Journal pg 315.

Mergendoller, J.R, Maxwell, N.L \& Bellisimo, Y. (2000). Problem based learning and high school: A comparative study of instructional method. Journal of educational research; Jul/Aug 2000; 93,6 Proques Educational Journal pg 374 
Muhson, A. (2009). Peningkatan minat belajar dan pemahaman mahasiswa melalui penerapan PBL. 39. Jurnal UNY.

Middleton, J.A, \& Spanias, P.A. (2013). Motivation for Achievement in Mathematics: Findings, Generalizations, and Criticisms of the Research. Journal for Research in Mathematics Education, 30(1),65-88.

Muijs, D., \& Reynolds, D. (2011). Effective teaching teori dan aplikasi. Los Angeles: SAGE.

Nitko,A\& Brookhart,S. (2007). Educational assesment of Students. (6 $6^{\text {th }}$ ed.) Boston: Pearson Education, Inc.

Ormrod, J. E. (2003). Educational psychology: developing learners. Upper Saddle River, NJ: Merrill Pretice Hall.

Rencher, A. C.(1998). Methods of multivariate analysis. Canada: John Willey \& Sons, Inc.

Santrock, J.W. (2009). Psikologi pendidikan (Terjemahan Tri Wibowo).New York, NY: McGraw Hill. (Buku asli diterbitkan tahun 2004).

Savickas, M. L., \& Spokane, A. R. (1999). Vocational interests: meaning, measurement, and counseling use. Palo Alto: Davies-Black Publishing.

Sax, G. (1980). Principles of educational and psychological measurement and evaluation. California: Wadsworth.

Seifert, K. \& Sutton, R. (2009). Educational Psychology ( $\left.2^{\text {nd }} E d\right)$. Switzerland: Jacobs Fondation.

Slavin, R.E. (2006). Educational psychology theory and practice. ( $8^{\text {th }} e d$.). New York: Pearson.

Steven, J. (2009). Applied multivariat statistik for the social science $\left(5^{\text {th }}\right.$ ed.). Mahwah: Lawrence Erlbaum Associates, Publisher.

Schunk, D. H., Pintrich, P.R., \& Meece, J. L. (2010). Motivation in education: theory, research, and applications. Upper Saddle River, NJ: Pearson.

Tan, O.S. (2009). Problem based learning innovation: using problem to power learning in the $21^{\text {th }}$ century. Singapore: Learning Asia.

Uno, H.B. (2008). Teori motivasi \& pengukurannya analisis di bidang pendidikan. Jakarta: Bumi Aksara.

Wiliams, K. C. \& Williams, C. C. (2010). Five key ingredients for improving students motivation. [Versi Elektronik]. Research in Higher Educational Journal, p 1-23.

Winkel, W. S. (1999). Psikologi Pengajaran.. Jakarta: Grasindo.

Woolfolk, A. (2007). Educational psycology. Boston: Pearson Allyn and Barcon. 